\title{
Agricultural and Municipal Waste Water as a Source of Antibiotic-Resistant Enterococci
}

\author{
Š. CUPÁKOVÁ, J. LUKÁŠOVÁ
}

Department of Milk Hygiene and Technology, Faculty of Veterinary Hygiene and Ecology, University of Veterinary and Pharmaceutical Sciences Brno, Czech Republic

\section{Received September 6, 2002}

Accepted March 25, 2003

\section{Abstract}

Cupáková, Š., J. Lukášová: Agricultural and Municipal Waste Water as a Source of Antibiotic-Resistant Enterococci. Acta Vet. Brno 2003, 72: 123-129.

The occurrence of enterococci in different waste waters from two cattle farms in south and north Moravia and sewage treatment plant of the University of Veterinary and Pharmaceutical Sciences Brno, Czech Republic was investigated. Resistance and/or sensitivity of selected isolates was tested to various antibiotics. The samples were collected in the course of two years (1999-2000). The total counts of enterococci varied from $10^{3}$ to $10^{5}$ colony-forming units (CFU) per ml. Among 100 isolated strains 60 strains were identified as Enterococcus faecalis, 10 as Ent. durans as well as Ent. hirae, 8 strains were allotted to Ent. faecium, 5 to Ent. mundtii, 3 to Ent. gallinarum, 2 to Ent. casseliflavus, one strain was identified as Enterococcus spp. and one strain was not specified as enterococcus. The susceptibility to antibiotics was tested by both, the agar disk diffusion method and the microdilution method. The majority of enterococci $(95 \%)$ was resistant to more than one antibiotic tested, especially to clindamycin, penicillin, cephalotin, ofloxacin and tetracycline. No vancomycin-resistant strain was found. Our results confirm that agricultural and municipal waste waters might be an important source of antibiotic-resistant enterococci.

Enterococci, waste water, silage, liquid manure, cattle, antibiotic-resistance

Enterococci are a part of the common microflora in the gastrointestinal tract of warmblooded animals and birds. In addition they can occur in soil, surface or waste waters, on plants and vegetables (Franz et al. 1999).

Enterococci are now considered as the third most common pathogens causing nosocomial infections and "superinfections" in hospitalized patients, accounting for nearly $12 \%$ of these infections (Linden et al. 1999). The most common enterococci-associated infections are infections of the urinary tract, bacteremia, endocarditis, intra-abdominal and pelvic infections. The very consequential ones are neonate meningitis and bacteremia and central nervous system infections in adults (Murray 1990; Franz et al. 1999).

Vancomycin-resistant enterococci (VRE) represent a serious problem at present. They are usually isolated from environment, waste waters, animals, foods of animal origin. They still represent the worldwide problem for hospitalized patients, where the glycopeptide antibiotics vancomycin and teicoplanin are used in the therapy of several infections caused by Gram-positive bacteria (Klare et al. 1993; B orgen et al. 2001). The emergence of VRE in Europe is attached to the long-time use of the glycopeptide antibiotic avoparcin as a growth promoter for farm animals with the possibility of inducing cross-resistance to vancomycin. In 1997 it was banned in EU (Gros s o et al. 2000). Many studies indicate food animals as reservoirs of resistant enterococci which might be transmitted to humans through the food chain and represent a potential risk for the consumers (B ate s et al. 1994; B a ger et al. 1997; Klein et al. 1998; Gros so et al. 2000).

The aim of this study was to investigate the occurrence of enterococci in different kinds of agricultural and municipal waste waters and to test their sensitivity to selected antimicrobial agents. 


\section{Materials and Methods}

Samples

The occurrence of enterococci was studied in different waste waters during the years 1999-2000. The following samples were collected:

- 12 samples of mixed waste waters from litter bed and milking parlor and 5 samples of silage waste waters from a cattle farm in the district of Blansko, south Moravia;

- 6 samples of cattle liquid manure from a cattle farm in the district of Nový Jičín, north Moravia;

- 10 samples of waste waters affluent to the sewage treatment plant of the Veterinary university Brno, Czech Republic.

Bacterial strains

A total of 100 bacterial strains were isolated during the microbiological analysis of agricultural and municipal waste water. The samples were diluted according to ČSN ISO 7218.The total numbers of enterococci were determined by inoculation of $0.1 \mathrm{ml}$ of the respectived dilution of the sample onto Slanetz-Bartley agar (HiMedia, Mumbai, India), which contains $\mathrm{NaN}_{3}$ as a selective agent for enterococci. The plates were incubated at $37 \mathrm{C}$ for $24 \mathrm{~h}$. Three colonies with different but "enterococcal" colony morphology from all tested samples were picked up. The purity of the isolated strains was checked by the streak plate technique on blood agar (Blood agar base No. 2 , HiMedia, and sheep blood, Bioveta, Ivanovice na Hané, CZ) and Slanetz-Bartley agar (HiMedia).

Identification of isolated strains

The following tests were used for the identification of isolated strains: Gram staining, appearance of colonies on blood agar, catalase production, growth at $45^{\circ} \mathrm{C}$, in broth (tryptone glucose yeast extract broth, HiMedia) with $6.5 \%$ $\mathrm{NaCl}$ and at pH 9.6 (Havlová et al. 1993), growth on bile-esculin agar (Oxoid, Basingstoke, Hampshire, England). Phenotyping of selected isolates was done using the Api Rapid ID 32 Strep system (BioMerieux, L'Etoile, France) and completed by production of pyrrolidonyl arylamidase (PYRAtest, Pliva-Lachema, a.s., Brno, Czech Republic), motility and production of yellow pigment.

Tests of sensitivity to antimicrobial agents

The susceptibility to antibiotics was tested by the agar disc diffusion method (DD) and the microdilution method (MD) to show the minimal inhibition concentration of antibiotic used (MIC) as well.

Agar disc diffusion method

These antimicrobial discs were used: ampicillin (AMP), cephalotin (CLT), clindamycin (CLI), erythromycin (ERY), gentamycin (GEN), chloramphenicol (CMP), ofloxacin (OFL), penicillin (PEN), teicoplanin (TEI), tetracycline (TTC) and vancomycin (VAN, Oxoid). DD method was performed according to Urbáš ko vá (1999), the Mueller-Hinton agar (Oxoid) was used. Based on the measurement of inhibition zone diameters the strains were classified as "susceptible", "intermediate resistant" or "resistant" using the interpretation criteria given in NCCLS (1999) and for TEI according to Urbášková (1999).

\section{Microdilution method}

The microtitre plates Gram-plus Strepto for MIC testing (obtained from Trios, spol. s r.o., Prague, Czech Republic) were used. The following antimicrobial drugs and their breakpoints were used: $0.125 \mathrm{mg} \cdot \mathrm{l}^{-1}$ for benzylpenicillin (PEN), $0.25 \mathrm{mg} \mathrm{l^{-1 }}$ for clindamycin (CLI), $0.5 \mathrm{mg} \cdot \mathrm{l}^{-1}$ for erythromycin (ERY), $2 \mathrm{mg} \cdot \mathrm{l}^{-1}$ for cephalotin (CLT), tetracycline (TTC) and ofloxacin (OFL), $4 \mathrm{mg} \cdot \mathrm{l}^{-1}$ for chloramphenicol (CMP) and vancomycin (VAN), $8 \mathrm{mg} \cdot 1^{-1}$ for ampicillin (AMP), ampicillin+sulbactam (AMS) and teicoplanin (TEI), $32 \mathrm{mg} \cdot \mathrm{l}^{-1} \mathrm{for}$ nitrofurantoin (FUR). After inoculation of $10 \mu$ of standardized bacterial suspension into each well, the microtitre plates were incubated for $24 \mathrm{~h}$ at $37^{\circ} \mathrm{C}$ and the growth of bacteria was measured at $630 \mathrm{~nm}$ using the Plate Reader (Morwell Diagnostics GmBH, Zurich, Switzerland). MIC value, $\mathrm{MIC}_{50}, \mathrm{MIC}_{90}$ and $\mathrm{MIC}$ range were defined for each tested strain and antimicrobial drug. The isolates were classified as "susceptible" or "resistant" using the interpretation criteria for MIC given in NCCLS (1995).

\section{Results}

Total counts of enterococci in samples varied from $10^{3}-10^{4}$ (waste waters from the farms) to $10^{5} \mathrm{CFU}$ per $\mathrm{ml}$ (area of the university). Among 100 isolated strains, the following species were identified; 60 strains of Enterococcus faecalis (60\%), 10 strains of Ent. durans (10\%) as well as of Ent. hirae (10\%), 8 strains of Ent. faecium (8\%), 5 strains of Ent. mundtii (5\%), 3 strains of Ent. gallinarum (3\%), two of Ent. casseliflavus (2\%) and one strain (1\%) of Enterococcus spp. One isolated strain was not specified as enterococcus. All isolated strains 
were Gram-positive and catalase negative cocci. They grew at $45{ }^{\circ} \mathrm{C}$, in $6.5 \% \mathrm{NaCl}$ broth, at $\mathrm{pH} 9.6$ and on bile-esculin agar. All strains produced pyrrolidonyl arylamidase. Enterococcal species isolated from various kinds of agricultural waste waters are summarized in Table 1.

Table 1

Numbers of strains of Enterococcus spp. isolated from different agricultural waste waters

\begin{tabular}{|l|c|c|c|c|}
\hline \multicolumn{1}{|c|}{ Species } & $\begin{array}{c}\text { Mixed waste } \\
\text { water } \\
\text { farm I. }\end{array}$ & $\begin{array}{c}\text { Silage waste } \\
\text { water } \\
\text { farm I. }\end{array}$ & $\begin{array}{c}\text { Cattle liquid } \\
\text { manure } \\
\text { farm II. }\end{array}$ & $\begin{array}{c}\text { Waste water } \\
\text { from area } \\
\text { of the university }\end{array}$ \\
\hline Ent. faecalis & 30 & 6 & 19 & 5 \\
Ent. durans & 8 & 2 & 0 & 0 \\
Ent. hirae & 5 & 1 & 3 & 1 \\
Ent. faecium & 2 & 4 & 2 & 0 \\
Ent. mundtii & 1 & 1 & 2 & 0 \\
Ent. gallinarum & 1 & 0 & 0 & 0 \\
Ent. casseliflavus & 0 & 2 & 0 & 0 \\
Enterococcus spp. & 1 & 0 & 2 & 0 \\
\hline
\end{tabular}

Resistance to antibiotics of isolated enterococci performed by agar disc diffusion method is shown in Table 2. The majority of tested isolates were resistant to CLI (98.99\%) and OFL (90.91\%). More than a half of the isolates was resistant to CLT and PEN (66.67\%). No strain was resistant to vancomycin and teicoplanin; only 32 strains shown VAN-intermediate resistance. The strains were resistant at least to one and not more than to seven antibiotics tested. The majority of strains was simultaneously resistant to four $(37.37 \%)$ or five $(26.26 \%)$ drugs. The most frequently occurring resistant phenotypes were CLI-CLT-OFLPEN (27 strains) and CLI-CLT-OFL-PEN-TTC (21 strains).

In terms of the MIC for the individual anti-microbial drugs, resistance to CLT, PEN and CLI was demonstrated in more than $95 \%$ of enterococcal strains and more than a half of them

Table 2

Survey of antibiotics resistance of isolated enterococci (agar disc diffusion method)

\begin{tabular}{|l|c|c|c|c|c|c|c|c|}
\hline \multirow{2}{*}{$\begin{array}{c}\text { Antimicrobial } \\
\text { agent }\end{array}$} & \multirow{2}{*}{$\begin{array}{c}\text { Disc } \\
\text { content } \\
{[\mu \mathrm{g}]}\end{array}$} & $\begin{array}{c}\text { Zone diameter } \\
\text { for susceptible } \\
\text { strain }[\mathrm{mm}]\end{array}$ & \multicolumn{2}{|c|}{$\begin{array}{c}\text { Susceptible } \\
\text { strains }\end{array}$} & \multicolumn{2}{c|}{$\begin{array}{c}\text { Intermediate } \\
\text { resistant strains }\end{array}$} & \multicolumn{3}{c|}{$\begin{array}{c}\text { Resistant } \\
\text { strains }\end{array}$} \\
\cline { 5 - 9 } & & No. & $\%$ & No. & $\%$ & No. & $\%$ \\
\hline Ampicillin & 10 & $\geq 17$ & 95 & 95.96 & - & - & 4 & 4.04 \\
Cephalotin & 30 & $\geq 18$ & 13 & 13.13 & 20 & 20.20 & 66 & 66.67 \\
Clindamycin & 2 & $\geq 21$ & 1 & 1.01 & 0 & 0 & 98 & 98.99 \\
Erythromycin & 15 & $\geq 23$ & 72 & 72.73 & 19 & 19.19 & 8 & 8.08 \\
Gentamycin & 10 & $\geq 15$ & 76 & 76.77 & 12 & 12.12 & 11 & 11.11 \\
Chloramphenicol & 30 & $\geq 18$ & 88 & 88.89 & 3 & 3.03 & 8 & 8.08 \\
Ofloxacin & 5 & $\geq 21$ & 9 & 9.09 & - & - & 90 & 90.91 \\
Penicillin & $10 \mathrm{units}$ & $\geq 15$ & 33 & 33.33 & - & - & 66 & 66.67 \\
Teicoplanin & 30 & $\geq 14$ & 99 & 100.00 & - & - & 0 & 0 \\
Tetracycline & 30 & $\geq 19$ & 33 & 33.33 & 23 & 23.23 & 43 & 43.44 \\
Vancomycin & 30 & $\geq 17$ & 67 & 67.68 & 32 & 32.32 & 0 & 0 \\
\hline
\end{tabular}

interpretation criteria NCCLS (1999) and for TEI Urbášk ová (1999) 


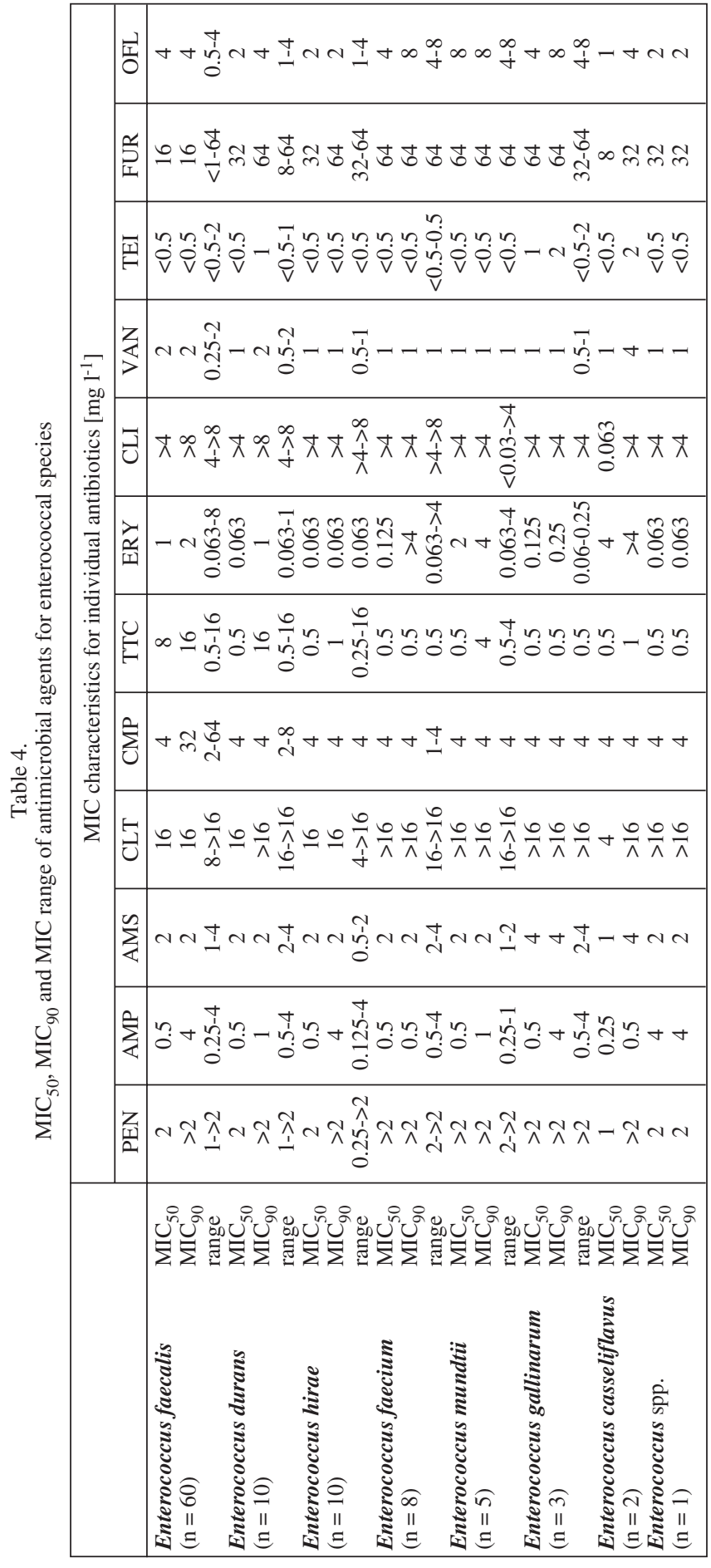

was resistant to $\mathrm{OFL}$ (56.56\%). Resistance to ERY was found in $45.45 \%$ of isolates; TTC was resisted by $40.40 \%$ of bacteria and FUR by $21.21 \%$. Only Ent. faecalis and Ent. durans were resistant to chloramphenicol. All strains were AMP, AMS, VAN and TEI sensitive. Out of the tested antibiotics the different resistance to TTC, ERY and OFL of enterococci isolated from the above mentioned sources was found (Table 3). The tested enterococci were simultaneously resistant at least to three and at the most to seven antibiotics examined; 41 strains were resistant to five antibiotics. The obtained values $\mathrm{MIC}_{50}, \mathrm{MIC}_{90}$ and MIC range of various antibiotics is demonstrated in Table 4.

\section{Discussion}

Enterococcus faecalis and Enterococcus faecium are the predominant species in water environment. Švec et al. (1999) studied 630 bacterial strains isolated from surface waters and 135 strains (21\%) were identified as Ent. faecium, 115 strains (18\%) were identified as Ent. faecalis. They assumed that also other identified species Ent. mundtii, Ent. casseliflavus, Ent. gallinarum, Ent. hirae and Ent. durans formed an important part of water environment. Similar re- 
Table 3

Numbers of antibiotic-resistant strains of Enterococcus spp. isolated from different sources (microdilution method)

\begin{tabular}{|l|c|c|c|c|c|c|c|c|}
\hline \multirow{2}{*}{$\begin{array}{c}\text { Antimicrobial } \\
\text { agent }\end{array}$} & \multicolumn{2}{c|}{$\begin{array}{c}\text { Mixed waste } \\
\text { water } \\
\text { farm I. }\end{array}$} & \multicolumn{2}{c|}{$\begin{array}{c}\text { Silage waste } \\
\text { water } \\
\text { farm I. }\end{array}$} & \multicolumn{2}{c|}{$\begin{array}{c}\text { Cattle liquid } \\
\text { manure } \\
\text { farm II. }\end{array}$} & \multicolumn{2}{c|}{$\begin{array}{c}\text { Waste water } \\
\text { from area of } \\
\text { the university }\end{array}$} \\
\cline { 2 - 9 } & $\mathrm{n}=48$ & $\%$ & $\mathrm{n}=16$ & $\%$ & $\mathrm{n}=28$ & $\%$ & $\mathrm{n}=7$ & $\%$ \\
\hline Ampicillin & 0 & 0 & 0 & 0 & 0 & 0 & 0 & 0 \\
Ampicillin+sulbactam & 0 & 0 & 0 & 0 & 0 & 0 & 0 & 0 \\
Benzylpenicillin & 48 & 100.0 & 16 & 100.0 & 28 & 100.0 & 6 & 85.7 \\
Cephalotin & 48 & 100.0 & 16 & 100.0 & 28 & 100.0 & 7 & 100.0 \\
Chloramphenicol & 6 & 12.5 & 1 & 6.3 & 6 & 21.4 & 1 & 14.3 \\
Clindamycin & 48 & 100.0 & 15 & 93.8 & 28 & 100.0 & 6 & 85.7 \\
Erythromycin & 25 & 52.1 & 10 & 62.5 & 8 & 28.6 & 2 & 28.6 \\
Nitrofurantoin & 6 & 12.5 & 8 & 50.0 & 6 & 21.4 & 1 & 14.3 \\
Ofloxacin & 18 & 37.5 & 13 & 27.1 & 21 & 75.0 & 4 & 57.1 \\
Teicoplanin & 0 & 0 & 0 & 0 & 0 & 0 & 0 & 0 \\
Tetracycline & 27 & 56.3 & 1 & 6.3 & 7 & 25.0 & 5 & 71.4 \\
Vancomycin & 0 & 0 & 0 & 0 & 0 & 0 & 0 & 0 \\
\hline
\end{tabular}

sults were obtained in other studies, which showed distribution of enterococci in sewage or waste waters, e.g. Valdivia et al. (1996) isolated 45 strains of enterococci from municipal waste waters; 32 of them were Enterococcus faecalis, 10 isolates belonged to Ent. faecium and three to Ent. hirae. Lauková et al. (1997) studied the occurrence of enterococci in municipal sewage from different sewage treatment plants in the Eastern Slovakia. They analyzed 2000 isolates and documented the predominant occurrence of Ent. faecium (50\%), followed by Ent. gallinarum (25.5\%) and Ent. casseliflavus (10.1\%). These presented studies suggest a higher incidence of Ent. faecium in municipal sewage and waste waters. Our results show an expressive prevalence of Enterococcus faecalis strains in different types of agricultural waste waters, which could be explained by the fact that the gastrointestinal tract of farm animals is probably more colonized by this species.

Most enterococci are naturally or inherently resistant to various drugs, including cephalosporins, oxacillin and to clinically achievable concentrations of clindamycin and aminoglycosides, a great part is relatively resistant to penicillin and ampicillin (Murray 1998; Urbášková 1999). Important is their resistance to tetracyclines, macrolides and chloramphenicol (Gray et al. 1991; Franz et al. 1999). Klare et al. (1993) showed that glycopeptide-resistant E. faecium can be found not only in clinical samples but also in environmental samples as well as in waste waters or sewage treatment plants. Our results are in agreement with these data. Schlegelová et al. (2002) described in their study resistance to TTC $\left(\mathrm{MIC}_{90}>32 \mathrm{mg} \mathrm{l}^{-1}\right)$ and to ERY $\left(\mathrm{MIC}_{90}>32 \mathrm{mg} \mathrm{l}^{-1}\right)$ among Enterococcus faecalis strains isolated from bulk milk samples. Compared to our results, $\mathrm{MIC}_{90} 16 \mathrm{mg} \mathrm{l}^{-1}$ for TTC and $\mathrm{MIC}_{90} 2 \mathrm{mg} \mathrm{l}^{-1}$ for ERY, a lower prevalence of resistant strains of Ent. faecalis was demonstrated.

Bates et al. (1994) isolated vancomycin-resistant E. faecium from a duck, a chick, a turkey, a dog, a pony and from pigs, but VRE were not isolated from cattle or sheep. Devriese et al. (1996) isolated VanA-resistant Ent. faecium strains from the intestines and faeces of horses, dogs, chickens and pigs, VanA-positive strains identified as Ent. durans from gallinaceous birds, Ent. faecalis in a horse and Ent. gallinarum in a pheasant. Furthermore, a prevalence of vancomycin-resistant Ent. faecium was studied in faecal samples from pigs in Spain. There, 43 from 240 pig farms represented in the sampling had 
at least one VRE-positive faecal sample (Herrero et al. 2000). Kolář et al. (2000) described for the first time the occurrence of VRE in animals in the Czech Republic. The VRE were isolated from $2.5 \%$ of examined hens and $75 \%$ of them was diagnosed as Ent. faecium phenotype VanA. In our study noVRE strain from agricultural waste water samples was detected.

Multidrug-resistant enterococci are commonly isolated from humans, sewage, aquatic habitats, agriculture and animal sources. It indicates their ability to enter the human food chain. Lauková et al. (1997) found that enterococci isolated from waste waters were resistant at least to one (except vancomycin) and not more than to six of the examined antibiotics, most of them being biresistant. Similarly, Kolář et al. (2000) reported about multiresistant enterococci isolated from hens. These findings are in accordance with our results. In this study $95 \%$ multiresistant strains of Enterococcus spp. in waste water samples were determined.

Finally, a large spectrum of enterococci was isolated and identified from various agricultural waste waters. Ent. faecalis predominated among them. The majority of enterococci were resistant to more than one antibiotics tested, above all to CLI, PEN, CLT, OFL and TTC. But no VRE strain was demonstrated. Our results suggest that agricultural waste waters might be an important source of resistant enterococci, which could be taken into account in their further application in agriculture.

\section{Odpadní vody jako zdroj antibotik-rezistentních enterokoků}

Byl sledován výskyt enterokoků v různých typech odpadních vod a testována jejich citlivost $\mathrm{k}$ různým druhům antibiotik. Vzorky byly získávány ze dvou farem skotu, z jižní a severní Moravy, a z čistírny odpadních vod Veterinární a farmaceutické univerzity Brno, Česká republika, a to v průběhu let 1999-2000. Celkový počet enterokoků se pohyboval $\mathrm{v}$ rozmezí $10^{3}$ až $10^{5} \mathrm{CFU} \cdot \mathrm{ml}^{-1}$. Z celkového počtu 100 izolovaných kmenů jsme identifikovaly 60 kmenů jako Enterococcus faecalis, 10 jako Ent. durans a Ent. hirae, 8 kmenů jako Ent. faecium, 5 jako Ent. mundtii, 3 jako Ent. gallinarum, 2 jako Ent. casseliflavus a jeden kmen byl identifikován jako Enterococcus spp. Jeden izolovaný kmen nebyl enterokok. Citlivost k antibiotikům byla testována dvěma metodami, a to agarovou diskovou difúzní metodou a mikrodiluční metodou. Převážná část enterokoků (95\%) byla rezistentní $\mathrm{k}$ více než jednomu testovanému antibiotiku, především ke klindamycinu, penicilinu, cefalotinu, ofloxacinu a tetracyklinu. Nezachytily jsme žádný vankomycinrezistentní kmen. Naše výsledky ukazují, že zemědělské a splaškové odpadní vody mohou být významným zdrojem enterokoků rezistentních k antibiotikům.

\section{Acknowledgements}

This study was supported by the grant of Ministry of Education, Youth and Sports of the Czech Republic No. 162700005 .

\section{References}

BAGER, F, MADSEN, M, CHRISTENSEN, J, AARESTRUP, FM 1997: Avoparcin used as a growth promoter is associated with the occurrence of vancomycin-resistant Enterococcus faecium on Danish poultry and pig farms. Prev Vet Med 31: 95-112

BATES, J, JORDENS, JZ, GRIFFITHS, DT 1994: Farm animals as a putative reservoir for vancomycin-resistant enterococcal infection in man. J Antimicrob Chemother 34: 507-516

BORGEN, K, SORUM, M, WASTESON, Y, KRUSE, H 2001: VanA-type vancomycin-resistant enterococci (VRE) remain prevalent in poultry carcasses 3 years after avoparcin was banned. Int J Food Microbiol 64: 89-94 DEVRIESE, LA, IEVEN, M, GOOSSENS, H, VANDAMME, P, POT, B, HOMMEZ, J, HAESEBROUCK, F 1996: Presence of vancomycin-resistant enterococci in farm and pet animals. Antimicrob Agents Chemother 40: $2285-2287$

FRANZ, CHMAP, HOLZAPFEL, WH, STILES, ME 1999: Enterococci at the crossroads of food safety? Int J Food Microbiol 47: 1-24 
GRAY, JW, STEWARD, D, PEDLER, SJ 1991: Species identification and antibiotic susceptibility testing of enterococci isolated from hospitalized patients. Antimicrob Agents Chemother 35: 1943-1945

GROSSO, MD, CAPRIOLI, A, CHINZARI, P, FONTANA, MC, PEZZOTTI, G, MANFRIN, A, GIANNATALE ED, GOFFREDO, E, PANTOSTI, A 2000: Detection and characterization of vancomycin-resistant enterococci in farm animals and raw meat products in Italy. Microb Drug Resis 6: 313-318

HAVLOVÁ, J, JIČÍNSKÁ, E, HRABOVÁ, H 1993: Microbiological methods in quality control of milk and milk products. UZPI, Prague, pp 126-133

HERRERO, IA, TESHAGER, T, GARDE, J, MORENO, MA, DOMINGUEZ, L 2000: Prevalence of vancomycinresistant Enterococcus faecium (VREF) in pig faeces from slaughterhouses in Spain. Prev Vet Med 47: 255-262

KLARE, I, HEIER, H, CLAUS, H, WITTE, W 1993: Environmental strains of Enterococcus faecium with inducible high-level resistance to glycopeptides. FEMS Microbiol Lett 106: 23-30

KLEIN, G, PACK, A, REUTER, G 1998: Antibiotic resistance patterns of enterococci and occurrence of vancomycin-resistant enterococci in raw minced beef and pork in Germany. Appl Environ Microbiol 64: 18251830

KOLÁŘ, M, BARDOŇ, J, VÁGNEROVÁ, I, HÁJEK, V, BZDIL, J, KOHNOVÁ, I, TYPOVSKÁ, H 2000: Occurrence of vancomycin-resistant enterococci in hens in the cenral region of Moravia. Vet Med - Czech 45: 93-97

LAUKOVÁ, A, JURIŠ, P 1997: Distribution and characterization of Enterococcus species in municipal sewages. Microbios 89: 73-80

LINDEN, PK, MILLER, CB 1999: Vancomycin-resistant enterococci: The clinical effect of a common nosocomial pathogen. Diagn Microbiol Infect Dis 33: 113-120

MURRAY, BE 1990: The life and times of the enterococcus. Clin Microbiol Rev 3: 46-65

MURRAY, BE 1998: Diversity among multidrug-resistant enterococci. Emerg Infect Dis 4: 37-47

National Committee for Clinical Laboratory Standards 1995: Performance standards for antimicrobial susceptibility testing. Sixth informational supplement M100-S6. NCCLS, Wayne.

National Committee for Clinical Laboratory Standards 1999: Performance standards for antimicrobial disk and dilution susceptibility tests for bacteria isolated from animals. Approved standard M31-A. NCCLS, Wayne.

SCHLEGELOVÁ, J, BABÁK, V, KLÍMOVÁ, E, LUKÁŠOVÁ, J, NAVRÁTILOVÁ, P, ŠUSTÁČKOVÁ, A, ŠEDIVÁ, I, RYŠÁNEK, D 2002: Prevalence of and resistance to anti-microbial drugs in selected microbial species isolated from bulk milk samples. J Vet Med B 49: 216-225

ŠVEC, P, SEDLÁČEK, I 1999: Occurrence of Enterococcus spp. in waters. Folia Microbiol 44: 3-10

URBÁŠKKOVÁ, P 1999: Resistance of bacteria to antibiotics - selected methods. Trios, spol. s r.o. Prague, pp. 1.110.2.8.

VALDIVIA, E, MARTIN-SANCHEZ, I, QUIRANTES, R, MARTINEZ-BUENO, M, GALVEZ, A, MAQUEDA, M 1996: Incidence of antibiotic resistance and sex pheromone response among enterococci isolated from clinical human samples and from municipal waste water. J Appl Bacteriol 81: 538-544

ČSN ISO 7218 Microbiology of food and animal feeding stuffs - General rules for microbiological examinations. ČNI Prague, pp. 39 